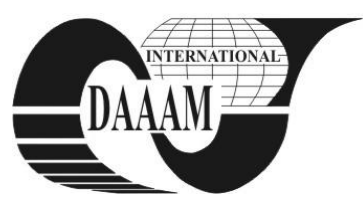

Annals of DAAAM for 2011 \& Proceedings of the 22nd International DAAAM Symposium, Volume 22, No. 1, ISSN 1726-9679 ISBN 978-3-901509-83-4, Editor B. Katalinic, Published by DAAAM International, Vienna, Austria, EU, 2011 Make Harmony between Technology and Nature, and Your Mind will Fly Free as a Bird Annals \& Proceedings of DAAAM International 2011

\title{
PROPOSAL OF WELDING TECHNOLOGY FOR TRIMETAL PRODUCTION
}

\author{
TURNA, M[ilan]; ONDRUSKA, J[ozef]; SAHUL, M[iroslav] \& TURNOVA, Z[uzana]
}

\begin{abstract}
The contribution deals with evaluation of quality of trimetal produced by explosion welding. Technically pure copper, aluminium and structural carbon steel were investigated as welded materials. Semtex $S 35$ was chosen as the explosive. Paralell set up of welded metals was used in the experiment. Optical microscopy, microhardness measurement across $\mathrm{Al}-\mathrm{Cu}$ - steel interface and EDX analysis were used for the quality control of the produced trimetal. The $\mathrm{Al}-\mathrm{Cu}$ interface turned out to be an irregularly wavy interface, while the $\mathrm{Cu}$ - steel interface was regularly undulated

Key words: explosion welding, copper, structural carbon steel, aluminium, quality control of welds
\end{abstract}

\section{INTRODUCTION}

In technical practice there is a large number of classic and special materials of high technical parameters such as welding and soldering technologies. They might be applied to join aluminum to steel and this was previously not common in order to achieve high quality of welded joints suitable for practical implementation.

For the production of bimetals of given combination of materials and overall dimensions using special welding methods for example cold pressure welding, diffusion welding or explosion welding.

Experiments concerning with this issue are solved all over the world. For example welding steel to copper with explosion (Durgutlu, 2005), laser beam remelting of steel - aluminium bimetal produced by explosion welding (Tricarico, 2010). The research is performing also in the field of simulation of welding process (Wang, 2011).

\section{EXPERIMENTAL}

Following materials were used for the experiment: base material 11373 steel according STN 411373 (S235JRG1 according EN 10025A1) with the thickness of $36 \mathrm{~mm}$, the $\mathrm{Cu}$ interlayer with the thickness of $2 \mathrm{~mm}$ and A199,9E as the main cladded plate (thickness of $16 \mathrm{~mm}$ ).

The final bimetal was pbtained by explosion welding. Paralell arrangement of the welded materials was used in experiment. The welding process was performed gradually. Copper was selected as the first material to be cladded. Subsequently, aluminium was cladded onto the produced steel - copper bimetal. Semtex S35 was used as an explosive in the experiment. Parameters of the Semtex S35explosive are given in Tab. 1.

\begin{tabular}{|l|c|c|}
\hline \multicolumn{1}{|c|}{ Name } & Designation & Value \\
\hline $\begin{array}{l}\text { The thickness of the lower } \\
\text { intelayer }\end{array}$ & $\mathrm{H}_{\mathrm{dm}}[\mathrm{mm}]$ & 9,605 \\
\hline $\mathrm{h}_{\mathrm{e}} / \mathrm{h}_{\mathrm{dm}}$ index & $\left(\mathrm{h}_{\mathrm{e}} / \mathrm{h}_{\mathrm{dm}}\right)<1$ & match \\
\hline Detonation density & $\rho_{\mathrm{E}}\left(\mathrm{g} \cdot \mathrm{m}^{-3}\right)$ & 1,145 \\
\hline $\begin{array}{l}\text { Ideal detonation velocity } \\
\text { at } \rho=1,0 \text { g.m }\end{array}$ & $\mathrm{v}_{\mathrm{dil}}\left[\mathrm{m}^{-3} \mathrm{~s}^{-1}\right]$ & 2044,20 \\
\hline
\end{tabular}

\begin{tabular}{|l|c|c|}
\hline $\begin{array}{l}\text { Change of detonation } \\
\text { velocity with density }\end{array}$ & $\mathrm{d}_{\mathrm{D}}$ & 3515,44 \\
\hline $\begin{array}{l}\text { Ideal detonation velocity at } \\
\text { arbitrary density }\end{array}$ & $\mathrm{v}_{\mathrm{di}}\left[\mathrm{m} \cdot \mathrm{s}^{-1}\right]$ & 2553,18 \\
\hline $\begin{array}{l}\text { Thickness of upper } \\
\text { interlayer }\end{array}$ & $\mathrm{h}_{\mathrm{hm}}[\mathrm{mm}]$ & 41,610 \\
\hline $\begin{array}{l}\text { Resultant detonation } \\
\text { velocity }\end{array}$ & $\mathrm{v}_{\mathrm{D}}\left[\mathrm{m} \cdot \mathrm{s}^{-1}\right]$ & 2251,92 \\
\hline Gurney velocity & $\left(2 \mathrm{E}_{\mathrm{G}}\right)^{1 / 2}\left[\mathrm{~m} \cdot \mathrm{s}^{-1}\right]$ & 1014,2 \\
\hline Detonation presses & $\mathrm{P}_{\mathrm{cj}}[\mathrm{GPa}]$ & 2,11 \\
\hline
\end{tabular}

Tab. 1. Parameters of used explosive

The parameters of collision for production of 11373 steel + $\mathrm{Cu}$ as well as parameters of collision for cladding of $\mathrm{Al}$ onto bimetal are in Tabs. 2, 3 .

\begin{tabular}{|l|c|c|}
\hline \multicolumn{1}{|c|}{ Name } & Designation & Value \\
\hline Time constant & $\mathrm{t}[\mu \mathrm{s}]$ & 5,35 \\
\hline $\begin{array}{l}\text { Deflection angle of the plate } \\
\text { at the selected distance }\end{array}$ & $\vartheta_{\mathrm{D}}[\mathrm{rad}]$ & 0,2614 \\
\cline { 2 - 3 } $\begin{array}{l}\text { Impact velocity at the selected } \\
\text { distance }\end{array}$ & $\mathrm{v}_{\mathrm{dD}}\left[\mathrm{deg} \cdot \mathrm{s}^{-1}\right]$ & 14,9771 \\
\hline $\begin{array}{l}\text { Velocity of collision point at } \\
\text { the selected distance }\end{array}$ & $\mathrm{v}_{\mathrm{kD}}\left[\mathrm{m} \cdot \mathrm{s}^{-1}\right]$ & 2256,98 \\
\hline
\end{tabular}

Tab. 2. Parameters of collision in cladding of $\mathrm{Cu}$ onto steel

\begin{tabular}{|l|c|c|}
\hline \multicolumn{1}{|c|}{ Name } & Designation & Value \\
\hline Time constant & $\mathrm{t}[\mu \mathrm{s}]$ & 5,35 \\
\hline $\begin{array}{l}\text { Deflection angle of the plate } \\
\text { at the selected distance }\end{array}$ & $\vartheta_{\mathrm{D}}[\mathrm{rad}]$ & 0,2614 \\
\cline { 2 - 3 } $\begin{array}{l}\text { Impact velocity at the } \\
\text { selected sistance }\end{array}$ & $\mathrm{v}_{\mathrm{DD}}[\mathrm{deg}]$ & 14,9771 \\
\hline $\begin{array}{l}\text { Velocity of collision point at } \\
\text { the selected distance }\end{array}$ & $\mathrm{v}_{\mathrm{kD}}\left[\mathrm{m} \cdot \mathrm{s}^{-1}\right]$ & 395,01 \\
\hline
\end{tabular}

Tab. 3. Parameters of collision in cladding of $\mathrm{Al}$ onto $\mathrm{Al}+$ steel bimetal

Overlaps of accelerated metals including explosives were selected in order to produce high quality joint up to the edge of the stable material (Fig. 1). In practice the overlaps are usually proposed to be as a multiple of the explosive thickness.

The following methods were used for evaluation of the quality of produced trimetal:

- macrostructural analysis

- microstructural analysis

- microhardness measurement across bimetal interface

- $\quad$ RTG microanalysis.

The macrostructure of trimetal is given in Fig. 1. It can be seen that the $\mathrm{Cu}$ - steel interface is regularly undulated. The presence of small islands was also observed. Wavy interface at the $\mathrm{Al}-\mathrm{Cu}$ side was also observed but it is not clearly visible due to the presence of other phases. 


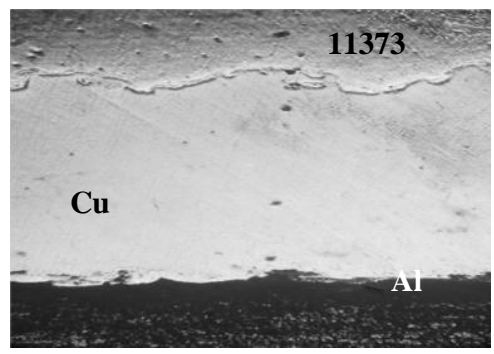

Fig. 1. Microstructure of 11373 steel-Cu-Al interface

Close to the interface the deformation of steel as well as of copper was recorded. The interface has the characteristic deformed structure. The grains lost their polyhedral shape. Increasing the distance from the interface it turns out that the microhardness decreases (Fig. 2).

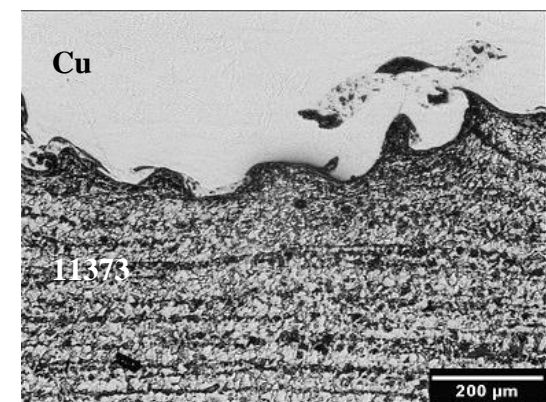

Fig. 2. 11373 steel - Cu interface

The microscopic analysis across the $\mathrm{Fe}-\mathrm{Cu}$ interface proved regularly wavy interface with a small wavelength $\lambda$. It is noticeable that the intermixing between $\mathrm{Cu}$ and structural carbon steel occured. At the interface the steel is deformed to a depth of $45 \mu \mathrm{m}$ measured from the bimetal interface.

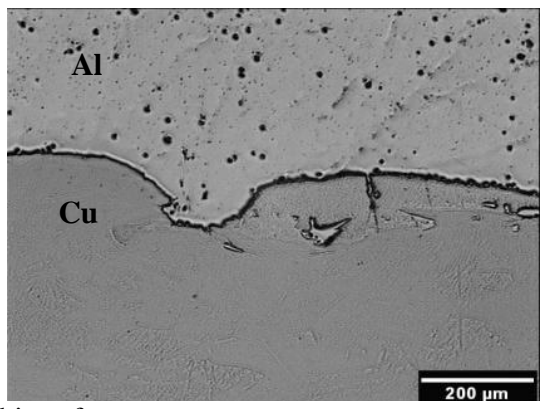

Fig. 3. $\mathrm{Cu}-\mathrm{Al}$ interface

$\mathrm{Cu}-\mathrm{Al}$ interface (Fig. 3) is characterised with irregular wavy interface with high wavelength. Measurement of microhardness (Fig. 4) confirmed the expected increase in hardness and thus the materials reinforced at the interface of trimetal.

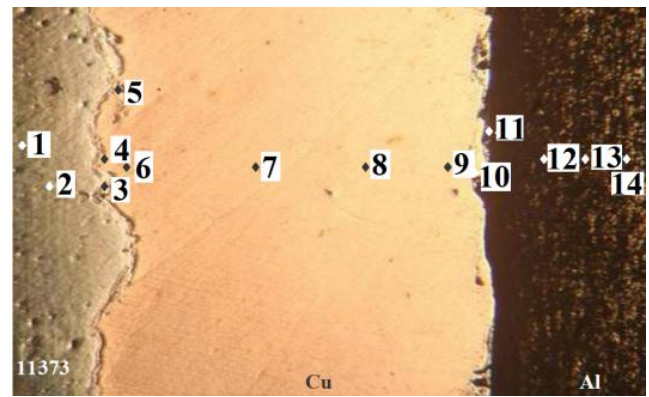

Fig. 4 Measurement of microhardness across the trimetal interface

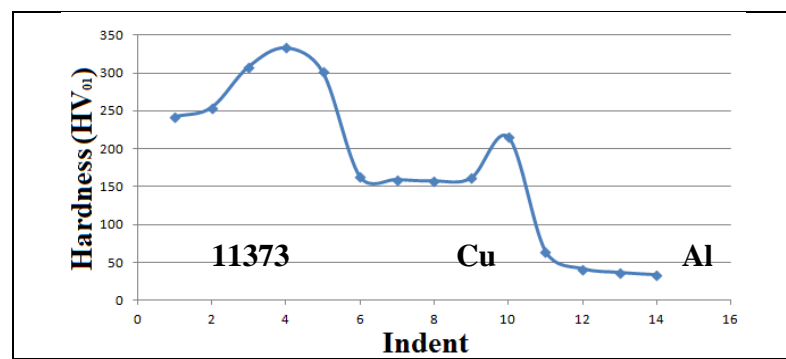

Fig. 5. Measurement of microhardness across the trimetal interface

EDX analysis confirmed the intermixing of the welded materials especially in case of Al-Cu which can be seen in Figs. 6. and 7.

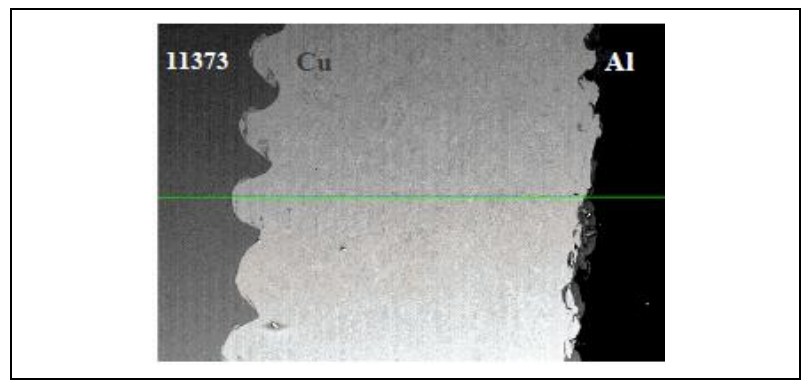

Fig. 6. Area studied by EDX analysis

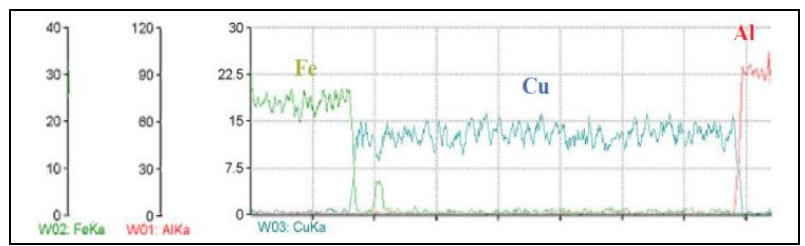

Fig. 7. Line concentration profiles of the selected elements

\section{CONCLUSION}

The paper deals with explosion welding of trimetal consisting of steel, copper and aluminium. Welded interfaces were examined by optical microscopy, microhardness measurement and EDX analysis. The mechanical intermixing was observed. Intermetalic compounds, such as $\mathrm{CuAl}_{2}$, $\mathrm{Cu}_{11} \mathrm{Al}_{9}, \mathrm{Cu}_{33} \mathrm{Al}_{17}, \mathrm{Cu}_{9} \mathrm{Al}_{4}$ and $\mathrm{Cu}_{4} \mathrm{Al}$ can be assumed according to Al-Cu binary diagram. SEM should be utilized for precise identification of the phases at interface. It can be concluded that the produced joints are suitable.

\section{ACKNOWLEDGMENT}

The submitted work was supported by the Slovak Grant agency VEGA MŠ VVŠ SR and SAV project No. 1/0842/09.

\section{REFERENCES}

Ahmet Durgutlu, a kol.: Examination of copper/stainless steel joints formed by explosive welding, Materials and Desing, Volume 26, Issue6, 2005, Pages 497-507

L. Tricarico, R. Spina.: Experimental investigation of laser beam welding of explosion-welded steel/aluminum structural transition joints, Materials and Desing, Volume 31, Issue 4, April 2010, Pages 1981-1992

Yuxin Wang, H.G. Beom, Ming Sun, Song Lin.: Numerical simulation of explosive welding using the material point method, International Journal of Impact Engineering, Volume 38, Issue 1, January 2011, Pages 51-60 